\title{
Efficacy and safety of convalescent plasma for severe COVID-19 based on evidence in other severe respiratory viral infections: a systematic review and meta-analysis
}

\author{
Niveditha Devasenapathy MBBS MSc, Zhikang Ye MPharm, Mark Loeb MD MSc, Fang Fang MD, \\ Borna Tadayon Najafabadi MD MPH, Yingqi Xiao MN, Rachel Couban MA MISt, Philippe Bégin MD PhD, \\ Gordon Guyatt MD MSc
}

Cite as: CMAJ 2020 July 6;192:E745-55. doi: 10.1503/cmaj.200642; early-released May 22, 2020

See related article at www.cmaj.ca/lookup/doi/10.1503/cmaj.200648

\begin{abstract}
BACKGROUND: The safety and efficacy of convalescent plasma in severe coronavirus disease 2019 (COVID-19) remain uncertain. To support a guideline on COVID-19 management, we conducted a systematic review and meta-analysis of convalescent plasma in COVID-19 and other severe respiratory viral infections.
\end{abstract}

METHODS: In March 2020, we searched international and Chinese biomedical literature databases, clinical trial registries and prepublication sources for randomized controlled trials (RCTs) and nonrandomized studies comparing patients receiving and not receiving convalescent plasma. We included patients with acute coronavirus, influenza and Ebola virus infections. We conducted a meta-analysis using randomeffects models and assessed the quality of evidence using the Grading of Recommendations Assessment, Development, and Evaluation (GRADE) approach.

RESULTS: Of 1099 unique records, 6 studies were eligible, and none of these included patients with COVID-19. One nonrandomized study $(n=40)$ on convalescent plasma in severe acute respiratory syndrome coronavirus (SARS-CoV) provided uninformative results regarding mortality (relative risk [RR] 0.10, 95\% confidence interval $[\mathrm{Cl}] \mathrm{Cl} 0.01$ to 1.70 ). Pooled estimates from 4 RCTs on influenza ( $n=572$ ) showed no convincing effects on deaths (4 RCTs, RR 0.94, 95\%
$\mathrm{Cl} 0.49$ to 1.81 ), complete recovery (2 RCTs, odds ratio $1.04,95 \% \mathrm{Cl} 0.69$ to 1.64) or length of stay (3 RCTs, mean difference $-1.62,95 \% \mathrm{Cl}-3.82$ to $0.58, \mathrm{~d}$ ). The quality of evidence was very low for all efficacy outcomes. Convalescent plasma caused few or no serious adverse events in influenza RCTs (RR 0.85, 95\% Cl 0.56 to 1.29 , low-quality evidence).

INTERPRETATION: Studies of nonCOVID-19 severe respiratory viral infections provide indirect, very low-quality evidence that raises the possibility that convalescent plasma has minimal or no benefit in the treatment of COVID-19 and low-quality evidence that it does not cause serious adverse events. oronavirus disease 2019 (COVID-19) has been diagnosed in nearly 3 million individuals around the globe, of whom around 0.2 million have died. ${ }^{1}$ Many patients with COVID19 develop severe acute respiratory illness requiring admission to intensive care units (ICU) and often mechanical ventilation. ${ }^{2}$ The case fatality rate in COVID-19 may be as high as $2.3 \%$ overall $^{2}$ and from $10 \%$ to $40 \%$ among severely affected individuals., There is an urgent need for effective therapies.

Emerging epidemiologic and clinical data show both similarities and differences between severe COVID-19 and severe acute respiratory syndrome (SARS) and Middle East respiratory syn- drome (MERS). ${ }^{5}$ Similarly, treatment strategies for severe influenza infections tested during the H1N1 pandemic and $\mathrm{H} 5 \mathrm{~N} 1$ and H7N9 outbreaks could inform the care of patients with severe COVID-19. ${ }^{6}$

Of the treatment options proposed for COVID- $19,{ }^{7}$ convalescent plasma has evidence suggesting a mortality benefit for Ebola virus infection. ${ }^{8}$ This intervention has also been tested in other severe acute viral respiratory infections. ${ }^{6,9,10}$ "Convalescent plasma" refers to plasma obtained from individuals recently recovered from a viral illness, which is expected to contain the highest levels of polyclonal antibodies directed against the 
virus. ${ }^{11}$ Similarly, "hyperimmune plasma" is collected from donors exhibiting high titres of neutralizing antibodies, independent of time elapsed since viral illness. Authors have used the terms interchangeably, and because viral neutralization is only one of the postulated mechanisms by which antibodies exert their antiviral effect, the importance of the distinction between the 2 products remains unclear (Figure 1 ).

Clinicians have typically administered convalescent plasma to patients with viral infections whose condition deteriorated despite supportive care. ${ }^{6}$ Although the primary postulated mechanism of action of convalescent plasma is reduction in viremia (passive immunity), ${ }^{12}$ an increase in host immune response (active immunity) has also been proposed. ${ }^{13}$ We describe in Figure 1 the possible mechanisms by which convalescent plasma inhibits severe acute respiratory syndrome coronavirus 2 (SARS-CoV-2).

Systematic summaries of the available evidence regarding safety and effectiveness can inform the use of convalescent plasma in patients with COVID-19. We therefore conducted a systematic review to summarize the evidence for convalescent plasma to support a guideline on COVID-19 management. ${ }^{14}$ Because we anticipated a paucity of direct evidence addressing the use of convalescent plasma in COVID-19, we summarized the available evidence addressing convalescent plasma in the treatment of SARS, MERS and influenza, including $\mathrm{H} 1 \mathrm{~N} 1, \mathrm{H} 7 \mathrm{~N} 9$ and $\mathrm{H} 5 \mathrm{~N} 1$, as well as addressing possible adverse effects in patients with Ebola disease.

\section{Methods}

This systematic review and meta-analysis follows PRISMA (Preferred reporting items for systematic reviews and meta-analyses) reporting guidelines. ${ }^{15} \mathrm{~A}$ supplementary file presents the systematic review protocol (Appendix 1, available at www.cmaj.ca/ lookup/suppl/doi:10.1503/cmaj.200642/-/DC1).

\section{Study selection}

We included studies of patients infected with SARS-CoV-2, SARSCoV, MERS-CoV or influenza virus with severe respiratory infection. For safety outcomes we also included data from Ebola virus infection. We used the COVID-19 definition of severe respiratory infection from the World Health Organization: fever or suspected respiratory infection, plus 1 of the following: respiratory rate $>30$ breaths/min, severe respiratory distress, or peripheral oxygen saturation $\left(\mathrm{SpO}_{2}\right) \leq 93 \%$ on room air. ${ }^{16}$ Eligible studies compared intravenous convalescent plasma or hyperimmune immunoglobulin against standard care management without use of convalescent plasma.

Outcomes of interest included mortality at longest follow-up, extent of recovery, length of ICU stay, length of hospital stay, days of mechanical ventilation and viral load. We also sought evidence of serious adverse outcomes, including complications related to intravascular volume overload and transfusion-related acute lung injury, allergy or anaphylaxis, and other serious adverse events.

For each patient population, we included only randomized controlled trials (RCTs) if they were available and dealt satisfactorily with issues of both benefit and harm. If RCTs were not available, or if nonrandomized comparative studies yielded important complementary information, we included nonrandomized studies with adjusted analysis and, if these were not available, any nonrandomized studies. We excluded studies with no comparator arm.

\section{Data sources and searches}

With the assistance of a medical librarian (R.C.), we searched health care databases (MEDLINE, Embase, PubMed for nonindexed studies and the Cochrane Central Register of Controlled Trials [CENTRAL]) on Mar. 6 and updated on Apr. 19, medRxiv (for nonpeer reviewed prepublication sources) on Mar. 11 and updated on Apr. 26, Chinese databases (China National Knowledge Infrastructure [CNKI], Wanfang, Chongqing VIP Information [CQVIP] and SinoMed) on Mar. 23 and updated on Apr. 21, and ChinaXiv on Apr. 26, 2020. The key search words were virus-related terms (coronavirus, influenza, Ebola, MERS, SARS) and interventionrelated terms (convalescent plasma and hyperimmune plasma). There were no restrictions by language. Appendix 1 presents the complete search strategy and summary of search results.

Two reviewers independently assessed titles and abstracts and, subsequently, for potentially eligible articles, the full text. Reviewers manually searched reference lists of eligible articles and published systematic reviews for eligible studies.

\section{Data extraction and quality assessment}

Two reviewers independently abstracted data related to study and participant characteristics, collection method of plasma and methods to quantify antibodies in the convalescent or hyperimmune plasma, study outcomes and risk of bias assessment, using Excel spreadsheets. Reviewers resolved disagreement through discussion.

A modified Cochrane risk-of-bias tool for RCTs provided guidance for risk-of-bias assessment. ${ }^{17}$ The instrument identifies 6 possible sources of bias in RCTs: sequence generation, concealment of allocation, blinding, loss to follow-up, selective outcome reporting and other problems. A modified NewcastleOttawa tool for comparative cohort studies ${ }^{18}$ that identifies possible sources of bias in selection of participants, temporality of outcome relative to exposure, measurement of outcome, exposure and prognostic factors, balance in prognostic factors, balance in concomitant therapy across groups, and completeness of follow-up provided guidance for observational studies. For both instruments, responses for each item were "definitely yes" or "probably yes" (low risk of bias), and "probably no" or "definitely no" (high risk of bias). We judged the overall risk of bias for each outcome in each study as "low risk" if all domains were rated as low risk of bias and otherwise as high risk of bias. Details are available at www.evidencepartners.com/resources/ methodological-resources.

\section{Quality of evidence}

We evaluated the quality of the evidence using the Grading of Recommendations Assessment, Development, and Evaluation (GRADE) approach ${ }^{19}$ including considerations of risk-of-bias assessment, indirectness, inconsistency, imprecision and publication bias. We reported the level of evidence in Summary of Findings tables. ${ }^{20,21}$ 


\section{SARS-CoV-2 entry into host cell}

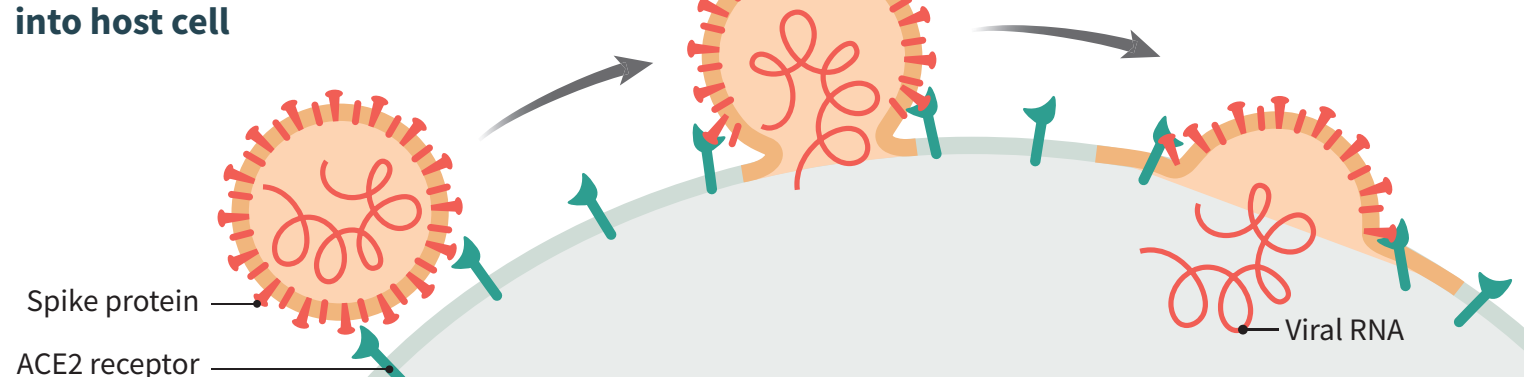

Host cell

Anti-SARS-CoV-2 antibodies: Four potential mechanisms of action

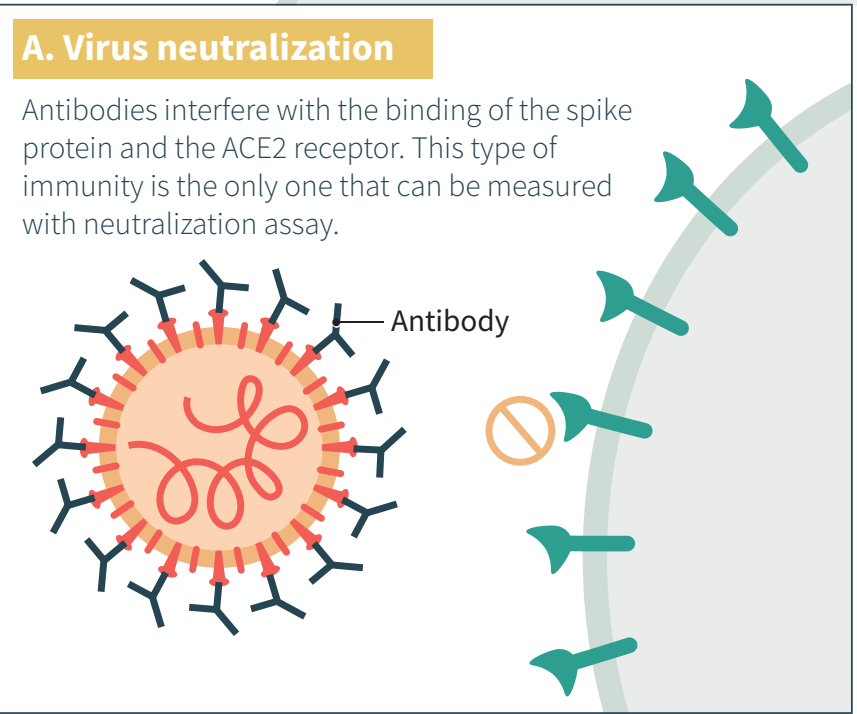

\section{B. Antibody-dependent virolysis}

Antibodies can activate the classical pathway of complement and virolysis. This type of immunity cannot be measured with neutralization assay.

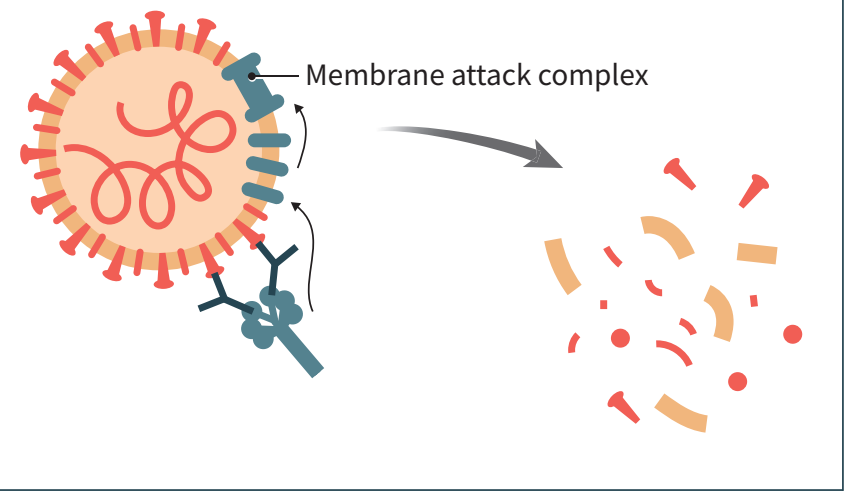

\section{Antibody-mediated presentation of antigen}

Antibodies combine with viral particles, which promotes uptake by antigen-presenting cells and activates a cellular-mediated immune response. This type of immunity cannot be measured with neutralization assay.
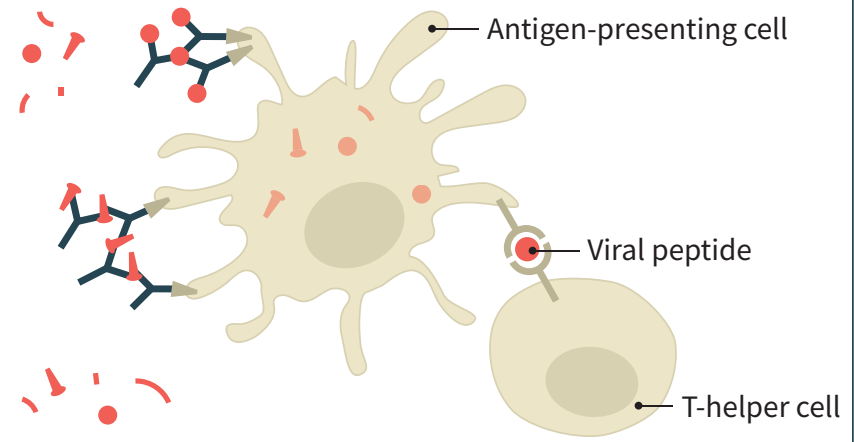

\section{Antibody-dependent cell cytotoxicity}

Antibodies on the host cell membrane allow natural killer cells to target infected cells for apoptosis. This type of immunity cannot be measured with neutralization assay.

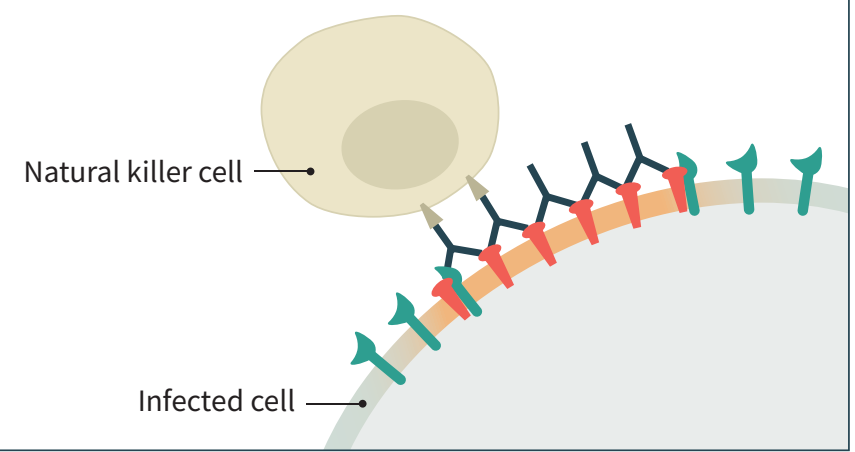

Figure 1: Potential mechanisms of action of anti-severe acute respiratory syndrome coronavirus 2 (SARS-CoV-2) antibodies in coronavirus disease 2019 (COVID-19). This figure illustrates the normal entry of SARS-CoV-2 in a host cell, in which membrane fusion is mediated by the interaction between the SARS-CoV-2 spike glycoprotein (red) and the angiotensin-converting enzyme 2 (ACE2) receptor (green) on the host cell, either through the cytoplasmic or endosomal route. Antibodies directed against the receptor-binding domain (RBD) of the spike protein can interfere with its interaction with the ACE2 receptor and prevent viral entry in the host cell (panel A). Antibodies directed against epitopes outside the RBD can also exert antiviral functions through other mechanisms (panels B, C and D). The relative importance of these various functions in rescuing patients from an active SARS-CoV-2 infection is unknown. Importantly, neutralization assays generally used to qualify hyperimmune products measure only 1 of the 4 mechanisms depicted here and do not necessarily correlate with the others. 


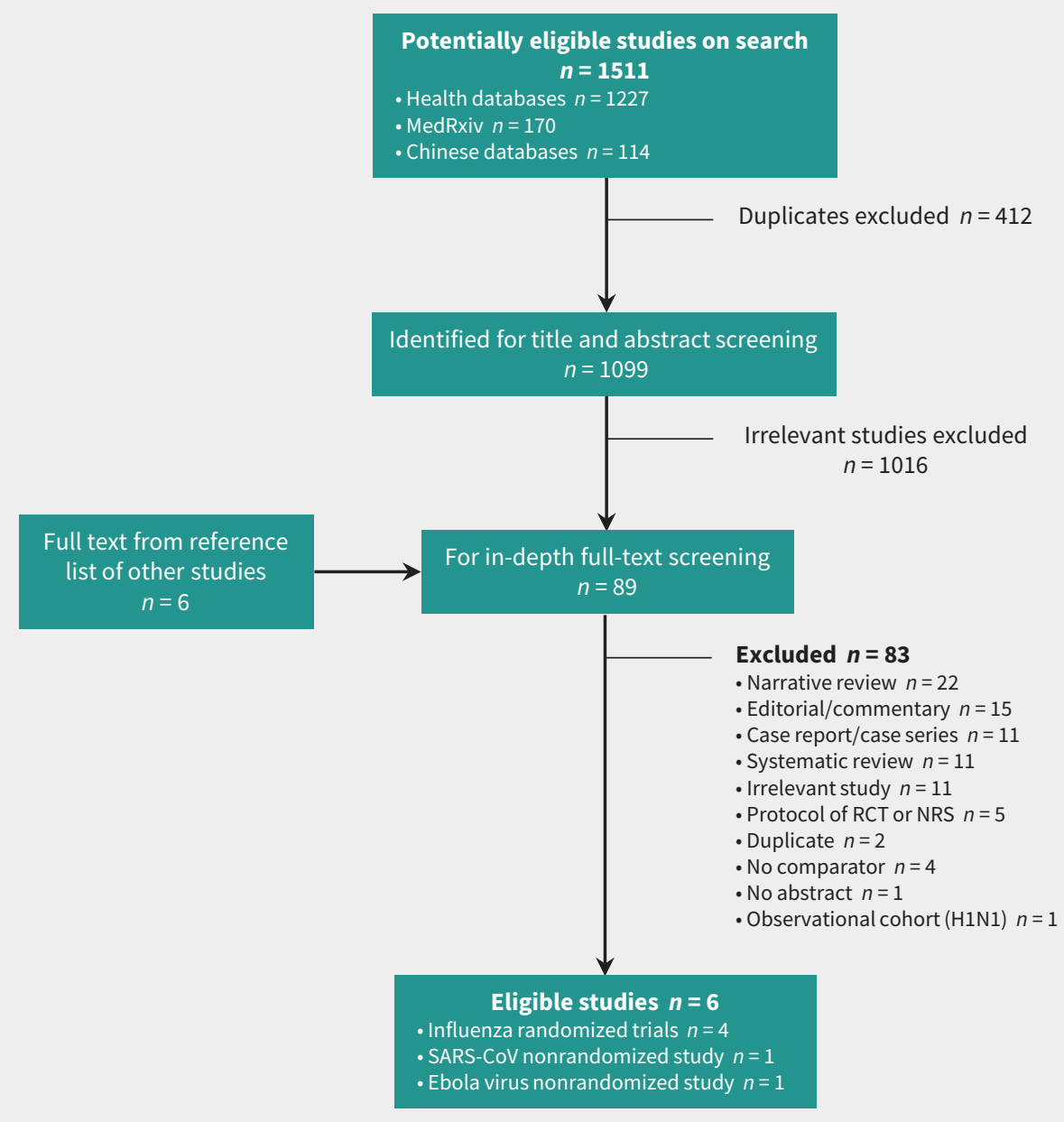

Figure 2: Study selection flow chart. Note: NRS = nonrandomized study, RCT = randomized controlled trial, SARS-CoV = severe acute respiratory syndrome coronavirus.

\section{Data analysis}

DerSimonian and Laird random-effects models were used for calculation of relative risks (RRs) for binary outcomes and proportional odds ratios (ORs) for ordinal outcomes, and 95\% confidence intervals (Cls). For continuous outcomes, we computed weighted mean differences (MDs) using DerSimonian and Laird random-effects models. For the purposes of pooling, if studies reported medians and interquartile ranges rather than means and standard deviations, we approximated means and standard deviation using the following formula: 75th percentile25th percentile)/1.35. ${ }^{22}$ We pooled effect estimates for each population by virus type. Anticipating a small number of studies, we did not plan funnel plots or statistical tests to explore publication bias, and we did not postulate subgroup effects. For computing risk differences (RDs) and $95 \% \mathrm{Cls}$, we applied pooled RRs and ORs to baseline risk estimates from studies of COVID-193 and, when not available, to the median baseline risk of control arms from the eligible studies. We used Stata 15 software for all analyses.

\section{Ethics approval}

Ethics approval was not required for this systematic review.

\section{Results}

The search yielded 1099 articles after removal of duplicates. The PRISMA flow chart (Figure 2), presents the reasons for excluding studies at the time of full-text review. No eligible studies of COVID-19 were identified. Six studies ${ }^{23-28}$ (Table 1) proved eligible, including 4 RCTs involving patients infected with influenza virus. ${ }^{24-27}$ One nonrandomized study related to SARS-CoV ${ }^{23}$ also provided evidence of effectiveness. We obtained safety data from the influenza RCTs ${ }^{24-27}$ and nonrandomized studies of Ebola virus disease ${ }^{28}$ and SARS-CoV. ${ }^{23}$

Of the 4 RCTs, 3 blinded patients and physicians $\mathrm{s}^{24,26,27}-2$ using low-titre intravenous immunoglobulin ${ }^{24,26}$ and 1 using saline infusion as a control ${ }^{27}$ - and 1 used an open-label design. ${ }^{25}$ Table 2 presents the risk of bias associated with mortality and length of stay. All RCTs except for $1^{25}$ were low in risk of bias (Table 2). 


\begin{tabular}{|c|c|c|c|c|c|c|c|c|}
\hline $\begin{array}{l}\text { Study; } \\
\text { year; } \\
\text { country }\end{array}$ & Study design & Disease & Intervention & Comparators & Sample size & $\begin{array}{l}\text { Median age } \\
\left(\text { IQR), }{ }^{\star} \mathrm{yr}\right.\end{array}$ & $\begin{array}{l}\text { ICU scoring } \\
\text { system; } \\
\text { median (IQR) } \\
\text { score }\end{array}$ & $\begin{array}{c}\text { Time } \\
\text { since } \\
\text { symptom } \\
\text { onset, } \\
\text { median } \\
\text { (IQR), d }\end{array}$ \\
\hline $\begin{array}{l}\text { Soo et al., } \\
2004,{ }^{23} \\
\text { Hong Kong }\end{array}$ & $\begin{array}{l}\text { Retrospective } \\
\text { cohort }\end{array}$ & $\begin{array}{l}\text { Hospital- } \\
\text { admitted } \\
\text { patients with } \\
\text { SARS-CoV }\end{array}$ & $\begin{array}{l}200-400 \mathrm{~mL} \text { of CP } \\
\text { (titre 1:160-1:2560) }\end{array}$ & $\begin{array}{l}\text { Methylprednisolone } \\
\text { ( } \geq 4 \text { doses; each } \\
\text { dose is a 500-mg } \\
\text { pulse) }\end{array}$ & $\begin{array}{l}\text { CP arm: } n=19 \\
\text { Control arm: } \\
n=21\end{array}$ & $\begin{array}{l}\text { CP arm: mean } \\
38.7 \text { (SD 12.39) } \\
\text { Control arm: } \\
\text { mean } 47.9 \text { (SD } \\
19.6)\end{array}$ & NR & NR \\
\hline $\begin{array}{l}\text { Hung } \\
\text { et al., } \\
2013,{ }^{24} \\
\text { Hong Kong }\end{array}$ & RCT & $\begin{array}{l}\text { Hospital- } \\
\text { admitted } \\
\text { patients with } \\
\text { H1N1 } \\
\text { influenza }\end{array}$ & $\begin{array}{l}\text { Single infusion of } \\
0.4 \mathrm{~g} / \mathrm{kg} \text { of H-IVIG } \\
\text { solution over } 4 \mathrm{hr} \text {; } \\
\text { NAbT > 1:40 }\end{array}$ & $\begin{array}{l}0.4 \mathrm{~g} / \mathrm{kg} \text { normal IVIG } \\
\text { prepared by } \\
\text { pharmacists; } \\
\mathrm{NAbT}<1: 10\end{array}$ & $\begin{array}{l}\text { CP arm: } n=17 \\
\text { Control arm: } \\
n=18\end{array}$ & $\begin{array}{l}\text { CP arm: } 43 \\
\text { (36.5 to } 56) \\
\text { Control arm: } \\
52 \text { (40.5 to } \\
58.5)\end{array}$ & $\begin{array}{l}\text { APACHE II; } \\
\text { CP arm: } 12 \\
\text { (8 to } 17.5 \text { ) } \\
\text { Control arm: } \\
13 \text { (9 to } 19 \text { ) }\end{array}$ & $\begin{array}{l}\text { CP arm: } \\
2 \text { (1 to } 4) \\
\text { Control } \\
\text { arm: } \\
3 \text { (2 to } 5)\end{array}$ \\
\hline $\begin{array}{l}\text { Beigel } \\
\text { et al., } \\
2019,{ }^{26} \text { US }\end{array}$ & RCT & $\begin{array}{l}\text { Hospital- } \\
\text { admitted } \\
\text { patients with } \\
\text { influenza A } \\
\text { (H1N1, H3N2) }\end{array}$ & $\begin{array}{l}2 \text { units high-titre } \\
\text { anti-influenza } \\
\text { plasma } \\
\text { (hemagglutination } \\
\text { inhibition titre } \\
\geq 1: 80 \text { ) }\end{array}$ & $\begin{array}{l}2 \text { units of low titre } \\
\text { plasma } \\
\text { (hemagglutination } \\
\text { inhibition titre, } \\
\leq 1: 10 \text { ) }\end{array}$ & $\begin{array}{l}\text { CP arm: } n=91 \\
\text { Control arm: } \\
n=47\end{array}$ & $\begin{array}{l}\text { CP arm: } \\
43 \text { (36.5 to } 56) \\
\text { Control arm: } \\
52 \text { ( } 40.5 \text { to } \\
58.5)\end{array}$ & $\begin{array}{l}\text { NEWS; } \\
\text { CP arm: } \\
5 \text { (4 to } 8 \text { ) } \\
\text { Control arm: } \\
5 \text { ( } 3 \text { to } 7) \\
\text { PELOD score; } \\
\text { CP arm: } \\
0 \text { (0 to } 1) \\
\text { Control arm: } \\
3 \text { ( } 1.5 \text { to } 12 \text { ) }\end{array}$ & $\begin{array}{l}\text { CP arm: } \\
3 \text { (2 to 5) } \\
\text { Control } \\
\text { arm: } \\
3 \text { (2 to } 4)\end{array}$ \\
\hline $\begin{array}{l}\text { van } \\
\text { Griensven } \\
\text { et al., } \\
2016,28 \\
\text { Guinea }\end{array}$ & $\begin{array}{l}\text { Prospective } \\
\text { non- } \\
\text { randomized } \\
\text { study }\end{array}$ & $\begin{array}{l}\text { Laboratory- } \\
\text { confirmed } \\
\text { Ebola virus } \\
\text { disease }\end{array}$ & $\begin{array}{l}2 \text { infusions } \\
200-250 \mathrm{~mL} \\
\text { ABO-compatible CP } \\
\text { (gap of } 2 \mathrm{~d} \text { ) }\end{array}$ & $\begin{array}{l}\text { Standard care } \\
\text { without CP }\end{array}$ & $\begin{array}{l}\text { CP arm: } n=99 \\
\text { Control arm: } \\
n=418\end{array}$ & $\begin{array}{l}\text { CP arm: } \\
29 \text { (0 to } 75) \\
\text { Control arm: } \\
28 \text { ( } 0 \text { to } 87)\end{array}$ & NR & $\begin{array}{l}\text { CP arm: } \\
19 \% \text { with } \\
>6 \mathrm{~d} \\
\text { Control } \\
\text { arm: } 49 \% \\
\text { with }>6 \mathrm{~d}\end{array}$ \\
\hline
\end{tabular}

Note: APACHE II = Acute Physiology and Chronic Health Evaluation II, CP = convalescent plasma, H-IVIG = hyperimmune intravenous immunoglobulin, ICU = intensive care unit, IQR = interquartile range, IVIG = intravenous immunoglobulin, NAbT = neutralizing antibody titres, NEWS = National Early Warning Score, NR = not reported, PELOD = Pediatric Logistic Organ Dysfunction, $\mathrm{RCT}=$ randomized controlled trial, SARS- $\mathrm{CoV}=$ severe acute respiratory distress syndrome coronavirus, $\mathrm{SD}=$ standard deviation .

*Unless stated otherwise.

The method of obtaining the hyperimmune sera varied across the RCTs. Only the trial reported by Hung and colleagues ${ }^{24}$ collected plasma from recently recovered donors (within 2 weeks) and quantified the antibody activity using neutralizing antibody titres. The other 3 trials ${ }^{25-27}$ obtained plasma from blood banks and included plasma from donors who recorded high doses of hemagglutination inhibition ( $\mathrm{HAl}$ ) titres and not necessarily from recently recovered individuals. All 3 RCTs reported very high levels of HAl titres (Table 1).

\section{Mortality}

For SARS-CoV, a small nonrandomized comparative study suggested very uncertain effects of convalescent plasma on mortality, based on unadjusted estimates (RR $0.10,95 \% \mathrm{Cl} 0.01$ to 1.70 , very low-quality evidence) ${ }^{23}$ (Figure 3 and Table 3 ).

Evidence from 4 RCTs $(n=572)$ of severely ill patients with influenza showed inconclusive effects of convalescent plasma on mortality between 7 and 28 days (RR $0.94,95 \% \mathrm{Cl} 0.49$ to 1.80 , very low-quality evidence) (Figure 3 and Table 3). Two RCTs in 
Table 2: Risk-of-bias assessment for mortality and length-of-stay outcomes using modified risk-of-bias criteria for randomized controlled trials and nonrandomized studies

\begin{tabular}{|c|c|c|c|c|c|c|c|c|}
\hline $\begin{array}{l}\text { Influenza trials, } \\
\text { mortality outcome }\end{array}$ & $\begin{array}{l}\text { Sequence } \\
\text { generation }\end{array}$ & $\begin{array}{c}\text { Allocation } \\
\text { concealment }\end{array}$ & $\begin{array}{l}\text { Blinding } \\
\text { (patients) }\end{array}$ & $\begin{array}{c}\text { Blinding } \\
\text { (health care } \\
\text { providers) }\end{array}$ & $\begin{array}{l}\text { Blinding } \\
\text { (outcome } \\
\text { assessors) }\end{array}$ & $\begin{array}{c}\text { Blinding } \\
\text { (data } \\
\text { collectors) }\end{array}$ & $\begin{array}{l}\text { Blinding (data } \\
\text { analyst) }\end{array}$ & $\begin{array}{l}\text { Loss to } \\
\text { follow-up }\end{array}$ \\
\hline Beigel et al., $2017^{25}$ & $\begin{array}{l}\text { Definitely } \\
\text { yes }\end{array}$ & Definitely yes & Definitely yes & Definitely no & Probably no & Definitely yes & Probably no & Definitely no \\
\hline Beigel et al., $2019^{26}$ & $\begin{array}{l}\text { Definitely } \\
\text { yes }\end{array}$ & Definitely yes & Definitely yes & Definitely yes & Definitely yes & Definitely yes & Definitely yes & Probably yes \\
\hline Davey et al., $2019^{27}$ & $\begin{array}{l}\text { Definitely } \\
\text { yes }\end{array}$ & Definitely yes & Definitely yes & Definitely yes & Definitely yes & Definitely yes & Definitely yes & $\begin{array}{l}\text { Definitely } \\
\text { yes }\end{array}$ \\
\hline Hung et al., $2013^{24}$ & $\begin{array}{l}\text { Definitely } \\
\text { yes }\end{array}$ & Definitely yes & Definitely yes & Definitely yes & Definitely yes & Definitely yes & Definitely yes & $\begin{array}{l}\text { Definitely } \\
\text { yes }\end{array}$ \\
\hline $\begin{array}{l}\text { Non-RCT (SARS-CoV), } \\
\text { mortality outcome }\end{array}$ & $\begin{array}{l}\text { Selection of } \\
\text { groups }\end{array}$ & $\begin{array}{c}\text { Exposure } \\
\text { assessment }\end{array}$ & $\begin{array}{l}\text { Outcome } \\
\text { following } \\
\text { exposure }\end{array}$ & $\begin{array}{c}\text { Baseline } \\
\text { comparability }\end{array}$ & $\begin{array}{c}\text { Measurement } \\
\text { of prognostic } \\
\text { variables }\end{array}$ & $\begin{array}{c}\text { Outcome } \\
\text { assessment }\end{array}$ & $\begin{array}{l}\text { Completeness } \\
\text { of follow-up }\end{array}$ & $\begin{array}{c}\text { Concomitant } \\
\text { treatments }\end{array}$ \\
\hline Soo et al., $2004^{23}$ & $\begin{array}{c}\text { Definitely } \\
\text { no }\end{array}$ & Probably yes & Definitely yes & Definitely no & Definitely no & Definitely no & Definitely no & Definitely no \\
\hline $\begin{array}{l}\text { Influenza trials, length } \\
\text { of stay }\end{array}$ & $\begin{array}{l}\text { Sequence } \\
\text { generation }\end{array}$ & $\begin{array}{c}\text { Allocation } \\
\text { concealment }\end{array}$ & $\begin{array}{c}\text { Blinding } \\
\text { (patients) }\end{array}$ & $\begin{array}{c}\text { Blinding } \\
\text { (health care } \\
\text { providers) }\end{array}$ & $\begin{array}{l}\text { Blinding } \\
\text { (outcome } \\
\text { assessors) }\end{array}$ & $\begin{array}{c}\text { Blinding } \\
\text { (data } \\
\text { collectors) }\end{array}$ & $\begin{array}{l}\text { Blinding (data } \\
\text { analyst) }\end{array}$ & $\begin{array}{l}\text { Loss to } \\
\text { follow-up }\end{array}$ \\
\hline Beigel et al., $2019^{26}$ & $\begin{array}{l}\text { Definitely } \\
\text { yes }\end{array}$ & Definitely yes & $\begin{array}{l}\text { Definitely } \\
\text { yes }\end{array}$ & Definitely yes & Definitely yes & Definitely yes & Definitely yes & Probably yes \\
\hline Hung et al., $2013^{24}$ & $\begin{array}{l}\text { Definitely } \\
\text { yes }\end{array}$ & Definitely yes & $\begin{array}{l}\text { Definitely } \\
\text { yes }\end{array}$ & Definitely yes & Definitely yes & Definitely yes & Definitely yes & $\begin{array}{l}\text { Definitely } \\
\text { yes }\end{array}$ \\
\hline Beigel et al., $2017^{25}$ & $\begin{array}{l}\text { Definitely } \\
\text { yes }\end{array}$ & Definitely yes & $\begin{array}{l}\text { Definitely } \\
\text { yes }\end{array}$ & Definitely no & Probably no & Definitely yes & Probably no & Definitely no \\
\hline
\end{tabular}

Note: $\mathrm{RCT}$ = randomized controlled trial, SARS-CoV = severe acute respiratory syndrome coronavirus.

patients with influenza reported a 6-item ordinal outcome relating to extent of recovery (death, in ICU, in hospital with oxygen support, in hospital without oxygen support, discharged but not fully recovered, discharged and fully recovered) at 28 days. ${ }^{25-27}$ The pooled OR for recovery (438 patients from $2 \mathrm{RCTs}^{26,27}$ ) was 1.05 (95\% $\mathrm{Cl} 0.67$ to 1.64$)$, representing very low-quality evidence (Figure 4 and Table 3).

\section{Length of hospital and ICU stay}

Evidence from $3 \mathrm{RCTs} \mathrm{s}^{24-26}$ in patients with severe influenza suggested possible but uncertain effects of convalescent plasma on decreasing length of hospital stay (weighted MD $-1.62,95 \% \mathrm{Cl}$ -3.82 to $0.58, d$ ), ICU stay (weighted MD $-0.32,95 \% \mathrm{Cl}-3.20$ to $2.56, \mathrm{~d}$ ) and duration of mechanical ventilation (weighted MD $-3.67,95 \% \mathrm{Cl}-7.70$ to $0.36, \mathrm{~d}$ ), providing very low-quality evidence in all cases (Figure 5 and Table 3).

\section{Reduction in viral load}

Pooled estimates from 2 RCTs $s^{25,27}$ in patients with severe influenza $(n=334)$ showed inconclusive effects of convalescent plasma on the proportion of patients with nondetectable levels of virus in nasopharyngeal specimens on day 3 (RR $1.07,95 \% \mathrm{Cl}$ 0.58 to 1.8 , very low-quality evidence) and a possible but uncertain increase in patients with undetectable virus on day $7^{25}$ (RR $1.32,95 \% \mathrm{Cl} 0.97$ to 1.81 , very low-quality evidence).
Harm

Pooled estimates from the 4 RCTs ${ }^{24-27}$ of patients with severe influenza $(n=576)$ suggested that convalescent plasma caused few or no serious adverse events (RR $0.85,95 \% \mathrm{Cl} 0.56$ to 1.29 , low-quality evidence) (Figure 6 and Table 3). Two RCTs s $^{25,26}$ reported transfusion-specific serious adverse reactions in 8 of 140 (6\%) patients in the convalescent plasma arm versus 6 of $96(6 \%)$ patients in the control arm. Nonrandomized studies of patients with SARS-CoV ${ }^{23}$ or Ebola virus ${ }^{28}$ infections and 1 RCT in patients with influenza ${ }^{24}$ reported no serious adverse events related to intravascular volume overload and transfusion-related acute lung injury or serious allergic reactions due to plasma transfusion.

\section{Interpretation}

Existing studies provide only very low-quality evidence to support inferences regarding benefits of convalescent plasma in patients with COVID-19. Based on low-quality evidence, there is no suggestion that convalescent plasma would cause any serious adverse events in patients with COVID-19.

On Mar. 25, 2020, the US Food and Drug Administration approved the use of convalescent plasma for COVID-19 under the emergency investigational new drug category and not for routine clinical use. ${ }^{29}$ Its inclusion in the expanded access program should not be perceived as an endorsement of efficacy, as the criteria for 


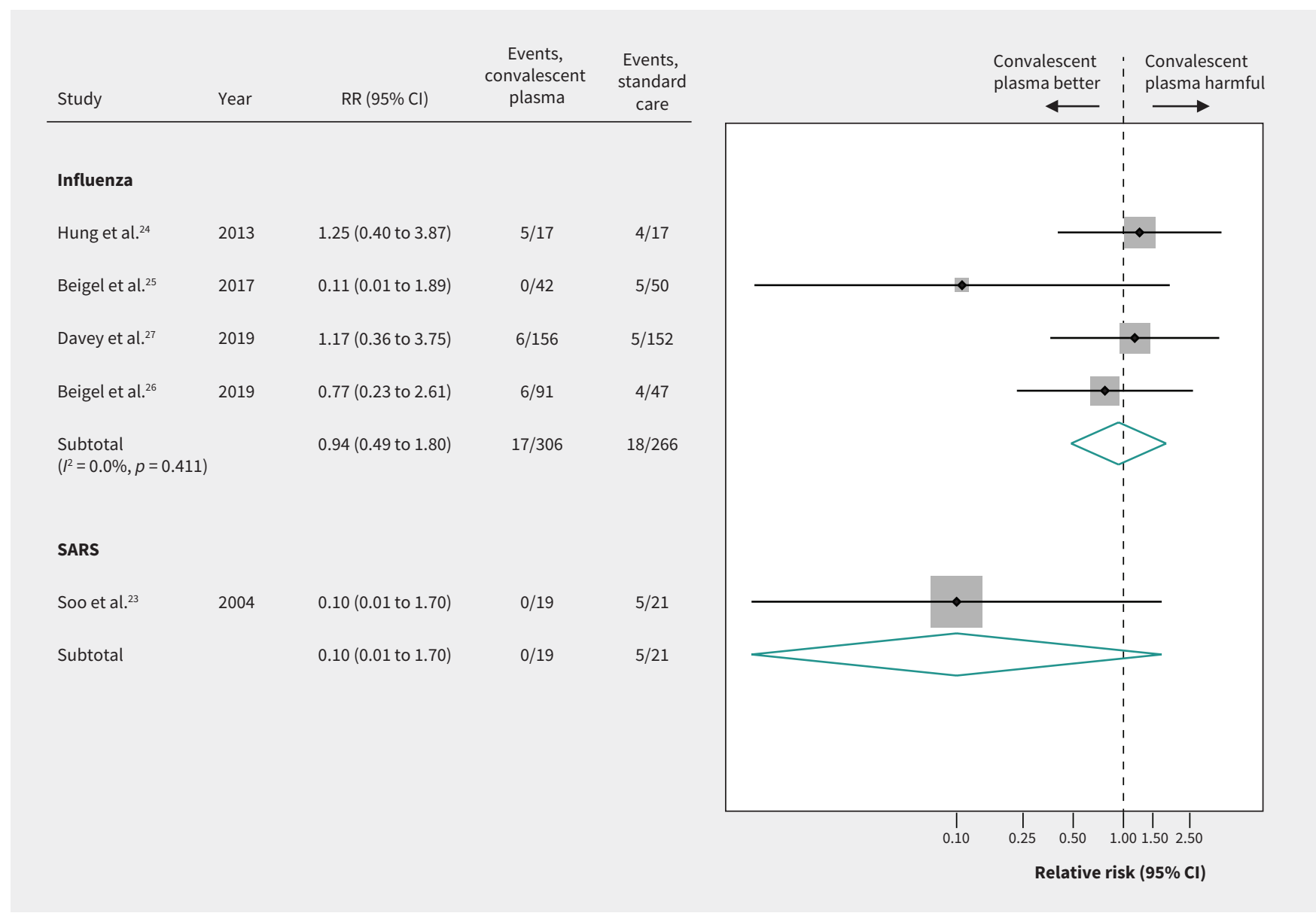

Figure 3: Efficacy of convalescent plasma on mortality in acute viral respiratory infections. Weights are from random-effects analysis. Note: $\mathrm{Cl}=$ confidence interval, $\mathrm{RR}=$ relative risk, $\mathrm{SARS}=$ severe acute respiratory syndrome.

the expanded access program is not demonstrated efficacy but rather lack of other approved therapeutic options or access to a clinical trial. Whether the limited evidence of benefit - or, in this case, of little or no benefit - is sufficient to justify compassionate use of an unproven intervention is a matter of debate. ${ }^{30}$

Strengths of this systematic review include the comprehensive search across databases for emerging and past evidence and use of the GRADE approach to assess the quality of evidence with attention to indirectness of the study populations in relation to patients with COVID-19. Eligibility decisions, risk-of-bias assessment, and data abstraction were all conducted in duplicate. We limited risk of bias by excluding single-arm studies.

A systematic review published in 2006 summarized evidence from 8 comparative observational studies addressing convalescent plasma ( $n=1703$ patients) conducted during the Spanish flu pandemic of $1918 .{ }^{10}$ The range of absolute RDs in mortality between patients who received convalescent plasma and control groups was $8 \%$ to $26 \%$ (pooled RD $21 \%, 95 \% \mathrm{Cl} 15 \%$ to $27 \%$ ). ${ }^{10}$ However, these observational studies with evident imbalance in prognostic factors provide only very low-quality evidence even for influenza, and thus the evidence is even lower quality when applied to COVID-19.

Similarly, a 2015 systematic review ${ }^{6}$ reported a very large mortality reduction (OR $0.25,95 \% \mathrm{Cl} 0.14$ to $0.45 ; P^{2}=0 \%$ ) in a post hoc meta-analysis of observational studies $(n=8)$ of convalescent plasma in severe SARS (1 retrospective cohort ${ }^{23}$ and 1 case series $^{31}$ ) and influenza A. Once again, this evidence is very low quality even for SARS, and thus even lower quality for COVID-19.

A recent systematic review ${ }^{32}$ that appeared on a non-peer reviewed preprint server ${ }^{33}$ pooled 5 influenza RCTs, of which $4 \mathrm{RCTS}^{24-27}$ are included in our review. ${ }^{32}$ The pooled mortality estimates were very similar to those of our review, OR $1.06(95 \% \mathrm{Cl}$ 0.51 to 2.23). However, the authors included a pilot trial of the International Network for Strategic Initiatives in Global HIV Trials, INSIGHT FLU005, ${ }^{34}$ thus double-counting patients included in the main trial. ${ }^{27}$ Further, this review did not pool the ordinal outcome (extent of recovery) and did not use GRADE methodology for rating the quality of the evidence. Most relevant for our review is the GRADE focus on assessing the indirectness of the evidence.

There are 3 studies reporting on the use of convalescent plasma in patients with severe COVID-19. One case series ${ }^{35}$ reported on 5 patients critically ill with COVID-19, of whom 3 were discharged and 2 improved, coincident with receipt of convalescent plasma. Another uncontrolled phase 1 study reported clinical improvement with resolution of lung lesions in 10 patients with severe COVID-19 who received convalescent plasma. ${ }^{36}$ Finally a case series of 4 patients, including 1 pregnant woman, also reported clinical improvement of all patients after transfusion. ${ }^{37}$ These uncontrolled case series are insufficient 
Patient or population: Children or adults with severe COVID-19 infection

Intervention: Convalescent or hyperimmune intravenous immunoglobulin

Comparison: Usual care + placebo (saline or intravenous immunoglobulin)

Absolute effects

\begin{tabular}{|c|c|c|c|c|}
\hline Outcome & $\begin{array}{c}\text { Relative effects, source of } \\
\text { evidence }\end{array}$ & $\begin{array}{l}\text { Baseline risk } \\
\text { for control } \\
\text { group (per } \\
1000 \text { ) }\end{array}$ & $\begin{array}{l}\text { Difference } \\
(95 \% \mathrm{CI})(\mathrm{per} \\
1000)\end{array}$ & $\begin{array}{c}\text { Certainty/quality of } \\
\text { evidence }\end{array}$ \\
\hline Mortality (7-28 d) & $\begin{array}{l}\text { RR } 0.94 \text { ( } 95 \% \mathrm{Cl} 0.49 \text { to } 1.80 \text { ) } \\
\text { Based on } 572 \text { patients with } \\
\text { influenza in } 4 \text { RCTs }\end{array}$ & $104^{\star}$ & $\begin{array}{c}-6 \\
(-53 \text { to } 84)\end{array}$ & $\begin{array}{l}\text { Very low } \oplus \Theta \Theta \Theta \\
\text { (Very serious indirectness and } \\
\text { serious imprecision) } \dagger\end{array}$ \\
\hline Mortality (22 d) & $\begin{array}{l}\text { RR } 0.10 \text { ( } 95 \% \mathrm{Cl} 0.01 \text { to } 1.70) \\
\text { Based on } 40 \text { patients with } \\
\text { SARS in } 1 \text { observational study }\end{array}$ & $104^{\star}$ & $\begin{array}{c}-94 \\
(-103 \text { to } 73)\end{array}$ & $\begin{array}{l}\text { Very low } \oplus \ominus \ominus \ominus \\
\text { (Serious indirectness, very } \\
\text { serious risk of bias and } \\
\text { serious imprecision) } \ddagger\end{array}$ \\
\hline $\begin{array}{l}\text { Recovery by } 28 \text { days as } \\
\text { measured by a } 6 \text {-point } \\
\text { ordinal scale§ }\end{array}$ & $\begin{array}{l}\text { Proportional OR for recovery§ } \\
\text { OR } 1.05 \text { ( } 95 \% \mathrm{Cl} 0.67 \text { to } 1.64 \text { ) } \\
\text { Based on } 438 \text { patients with } \\
\text { influenza from } 2 \text { RCTs }\end{array}$ & $104^{\star}$ & $\begin{array}{c}5 \\
(-30 \text { to } 56)\end{array}$ & $\begin{array}{l}\text { Very low } \oplus \Theta \Theta \Theta \\
\text { (Very serious indirectness and } \\
\text { serious imprecision) } \dagger\end{array}$ \\
\hline Length of hospital stay, $d$ & $\begin{array}{l}\text { Based on } 259 \text { patients with } \\
\text { influenza in } 3 \mathrm{RCTs}\end{array}$ & Median 13ฯ & $\begin{array}{c}M D-1.62 \\
(-3.82 \text { to } 0.58)\end{array}$ & $\begin{array}{l}\text { Very low } \oplus \Theta \Theta \Theta \\
\text { (Very serious indirectness and } \\
\text { serious imprecision) } \dagger\end{array}$ \\
\hline Length of ICU stay, $d$ & $\begin{array}{l}\text { Based on } 149 \text { patients with } \\
\text { influenza in } 2 \text { RCTs }\end{array}$ & Median $7^{\star \star}$ & $\begin{array}{c}\mathrm{MD}-0.32 \\
(\mathrm{Cl}-3.20 \text { to } \\
2.56)\end{array}$ & $\begin{array}{l}\text { Very low } \oplus \Theta \Theta \Theta \\
\text { (Very serious indirectness and } \\
\text { serious imprecision) } \dagger\end{array}$ \\
\hline $\begin{array}{l}\text { Time on mechanical } \\
\text { ventilation, } d\end{array}$ & $\begin{array}{l}\text { Based on } 83 \text { patients with } \\
\text { influenza in } 2 \text { RCTs }\end{array}$ & $\begin{array}{l}\text { Median } \\
9.25^{\star \star}\end{array}$ & $\begin{array}{c}\mathrm{MD}-3.67 \\
(\mathrm{Cl}-7.70 \text { to } \\
0.36)\end{array}$ & $\begin{array}{l}\text { Very low } \oplus \Theta \Theta \Theta \\
\text { (Very serious indirectness and } \\
\text { serious imprecision) } \dagger\end{array}$ \\
\hline Serious adverse events & $\begin{array}{l}\text { RR } 0.85 \text { (95\% Cl } 0.56 \text { to } 1.29) \\
\text { Based on } 576 \text { patients with } \\
\text { influenza in } 3 \text { RCTs }\end{array}$ & $80 \dagger \dagger$ & $\begin{array}{c}-12 \\
(-35 \text { to } 23)\end{array}$ & $\begin{array}{l}\text { Low } \oplus \oplus \Theta \Theta \\
\text { (Serious indirectness and } \\
\text { imprecision) } \ddagger \ddagger\end{array}$ \\
\hline
\end{tabular}

Plain-language summary

Convalescent plasma may have little to no effect on mortality, but the evidence is very uncertain.

Convalescent plasma could have an important effect on decreasing or increasing mortality, but the evidence is very uncertain.

Convalescent plasma may have little to no effect on recovery, but the evidence is very uncertain.

Convalescent plasma may confer small reduction in hospital length of stay, but the evidence is very uncertain.

Convalescent plasma may have little to no effect in reducing duration of ICU stay, but the evidence is very uncertain.

Convalescent plasma may reduce days of mechanical ventilation, but the evidence is very uncertain.

Convalescent plasma may result in little or no difference in the number of serious adverse events.

Note: $\mathrm{Cl}$ = confidence interval; COVID-19 = coronavirus disease 2019; GRADE = Grading of Recommendations Assessment, Development, and Evaluation; ICU = intensive care unit; $\mathrm{MD}=$ mean difference; $\mathrm{OR}=$ odds ratio; $\mathrm{RCT}=$ randomized controlled trial; $\mathrm{RR}=$ relative risk; $\mathrm{SARS}=$ severe acute respiratory syndrome.

*We chose the baseline risk from patients admitted to hospital with COVID-19 who did not receive convalescent plasma and steroids from the article by Guan et al. ${ }^{3}$ This paper reports 96/173 severely ill patients who did not receive steroids or hyperimmune plasma, of whom 10 patients died (Dr. W. Guan, State Key Laboratory of Respiratory Disease, National Clinical Research Center for Respiratory Disease, Guangzhou Institute of Respiratory Health, First Affiliated Hospital of Guangzhou Medical University, Guangzhou, Guangdong Province, China: personal communication, 2020). Hence, the baseline mortality risk is $10 / 96=10.4 \%$. The median duration of hospital admission was 12.0 days (mean $12.8 \mathrm{~d}$ ).

tWe rated down 2 levels for indirectness because clinical and epidemiologic characteristics of patients with influenza vary in COVID-19. We rated down 1 level for imprecision because the confidence interval included both important benefit and important harm.

łEvidence from observational studies begins as low-quality evidence. We rated down 1 level for indirectness because evidence came from SARS rather than COVID-19. We rated 1 level down for imprecision because the confidence intervals included both important benefit and important harm.

$\S$ Recovery defined by an ordinal outcome ( 6 mutually exclusive categories) at 28 days: death, in ICU, in hospital with oxygen support, in hospital without oxygen support, discharged but not fully recovered, discharged and fully recovered. An OR of $>1$ indicates treatment is better than control, interpreted as odds of better recovery is 1.24 times higher among those treated with hyperimmune plasma than control arm. This OR is similar across categories. We also assumed the risk differences between treatment groups is the same across categories of the outcome.

IWe chose the median duration of hospital admission from hospital-admitted COVID-19 patients with severe disease from the article by Guan et al. ${ }^{3}$

${ }^{\star \star}$ This is the median number of days in ICU obtained from the control arm of RCTs including patients with severe influenza.

t†The baseline risk of serious adverse events obtained from the control arm of studies including influenza (3 studies).

$\ddagger \ddagger W$ rated down 1 level for indirectness for this safety outcome, inferring that the adverse effects are likely to be similar across viral illnesses, and 1 level down for imprecision because the confidence intervals included both important benefit and important harm.

to question the inference from this review that benefits from convalescent plasma in patients with COVID-19 remain very uncertain. Recently, experimental monoclonal antibodies have shown promise in reducing mortality in Ebola virus disease. ${ }^{38}$ Generalization of results from these forms of passive immunization using highly standardized monoclonal antibodies selected for its antiviral potency to COVID-19 is, at best, very questionable.

\section{Limitations}

One important limitation of this review stems from the level of indirectness given that the majority of evidence comes from trials in influenza. Although this is the best evidence available in this urgent situation, the different biological, clinical and epidemiologic characteristics of influenza versus COVID-19 severely limit inferences regarding effects of convalescent plasma against the new virus. The unique 2-phase immune response observed in patients with severe 


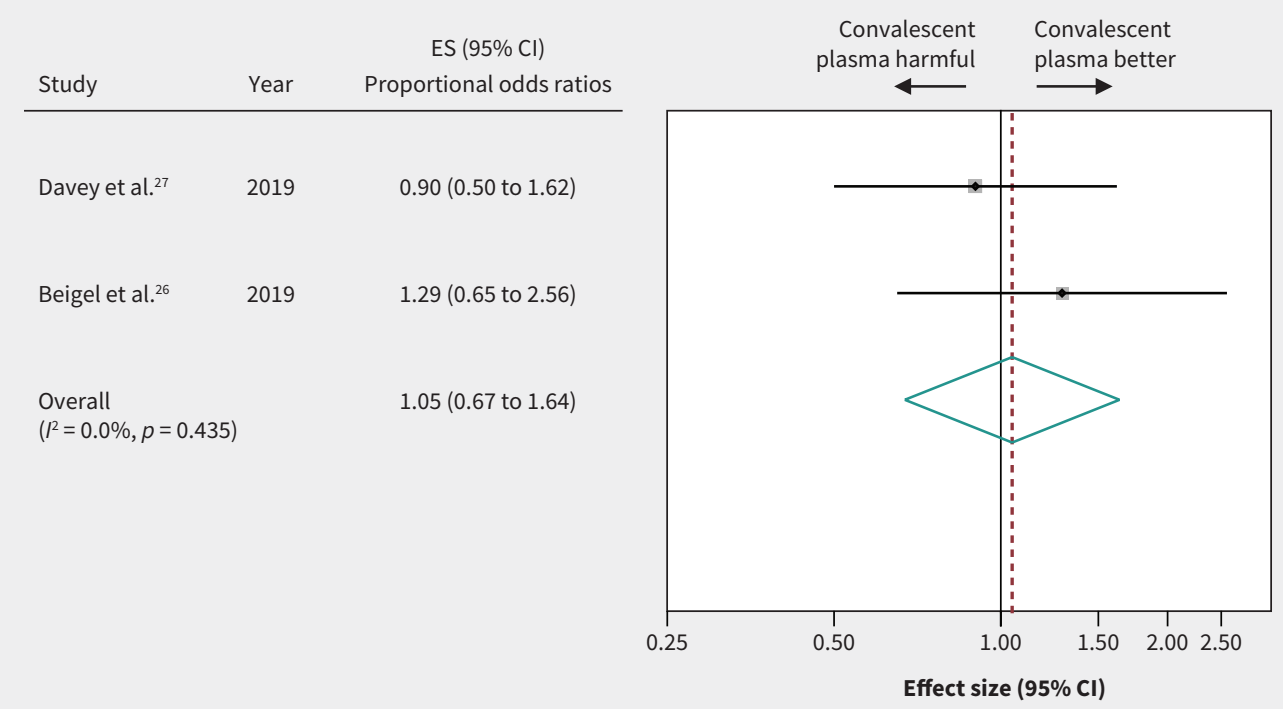

Figure 4: Efficacy of convalescent plasma in recovery from acute viral respiratory illness. Weights are from random-effects analysis. Note: $\mathrm{Cl}=$ confidence interval, $\mathrm{ES}=$ effect size.

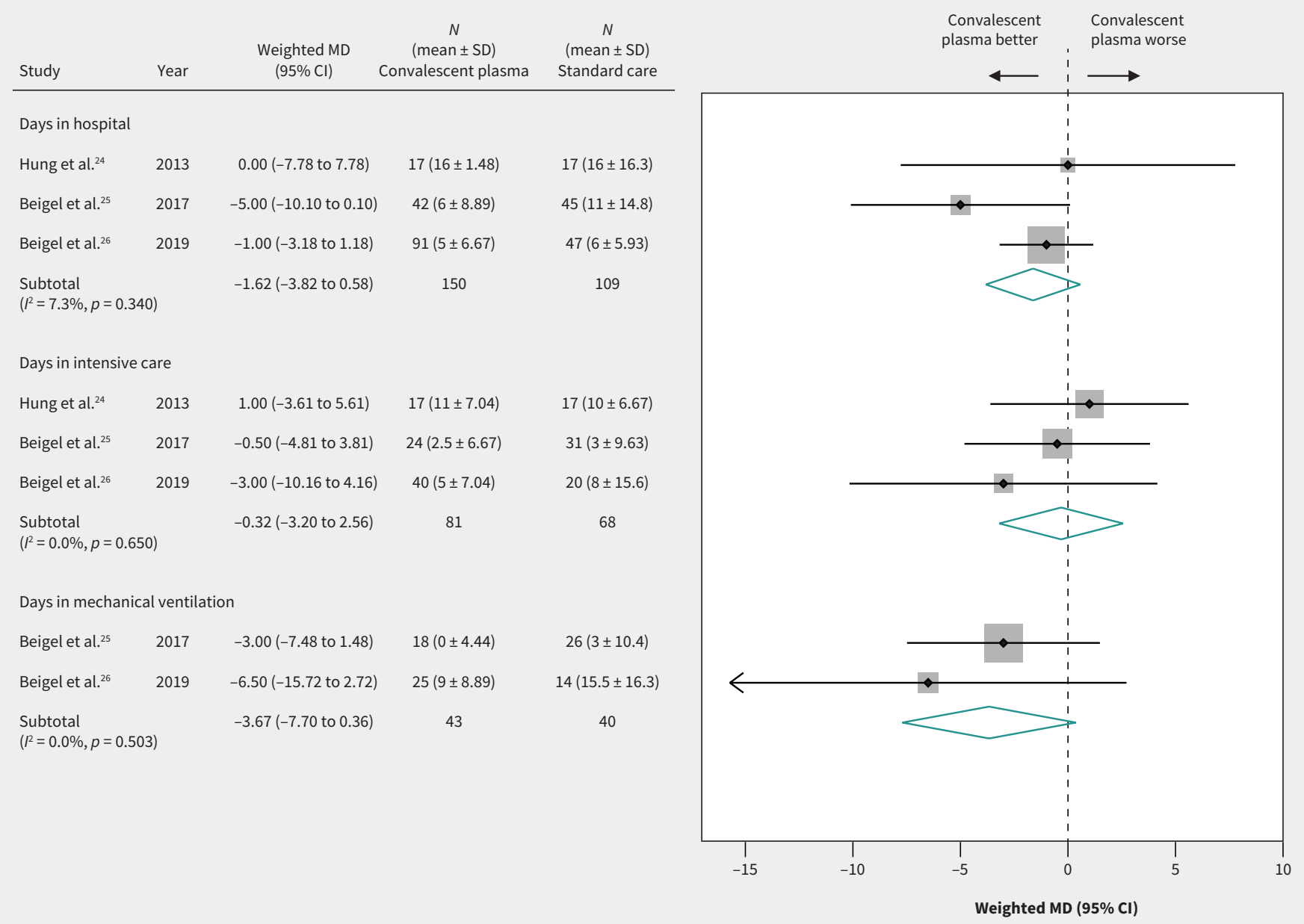

Figure 5: Efficacy of convalescent plasma in reducing length of hospital stay. Weights are from random-effects analysis. Note: $\mathrm{Cl}=$ confidence interval, $\mathrm{MD}=$ mean difference, $\mathrm{SD}=$ standard deviation . 


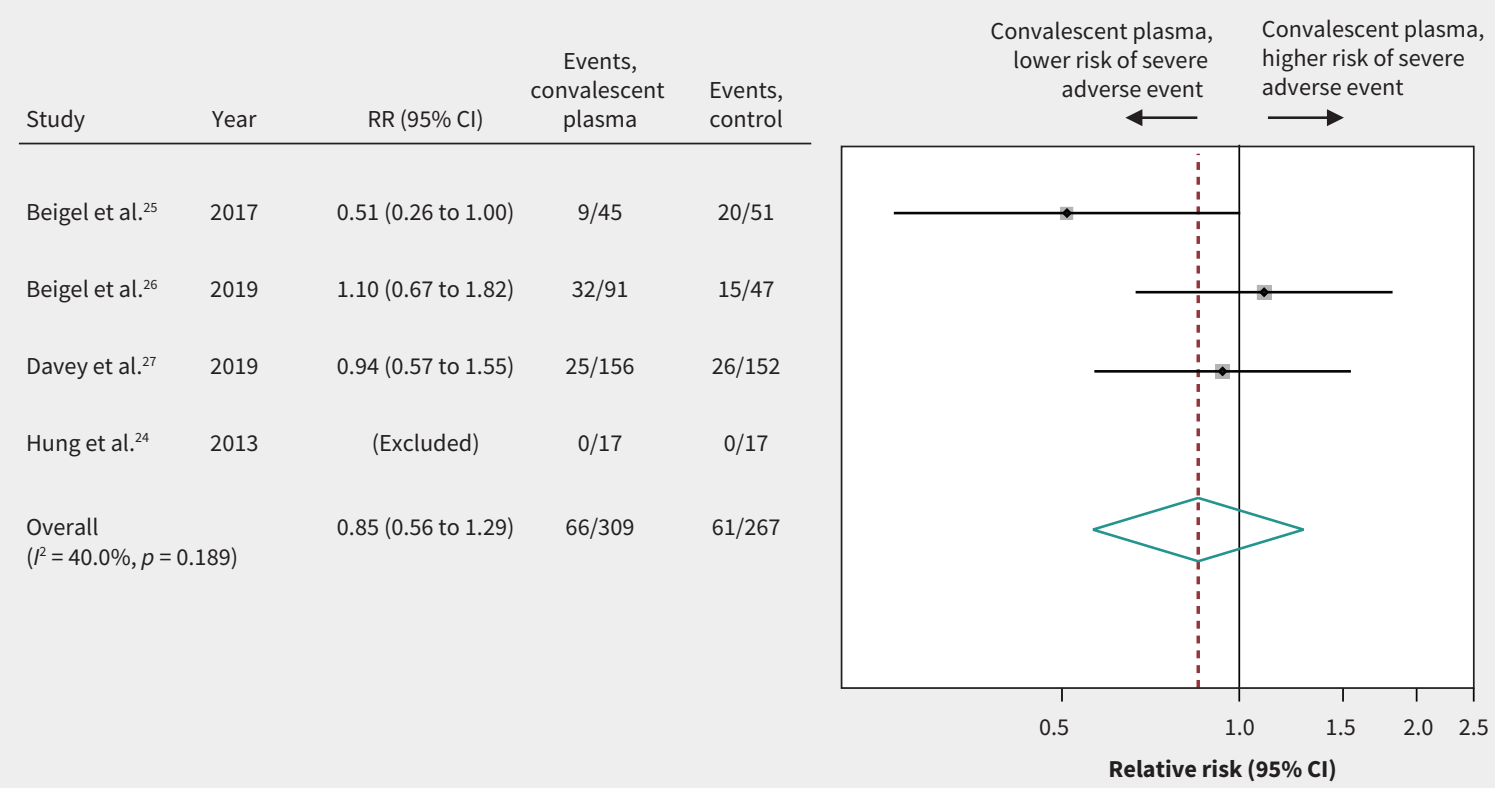

Figure 6: Safety of convalescent plasma. Weights are from random-effects analysis. Note: $\mathrm{Cl}=$ confidence interval, $\mathrm{RR}=$ relative risk .

coronavirus infections has direct implications for the potential effect of immune-boosting strategies. ${ }^{39}$ In addition, the small number of studies and events led to very wide confidence intervals, further lowering the quality of the evidence. Finally, because observational studies may provide additional evidence of harms, our restriction to randomized influenza trials represents, in this regard, a limitation.

Another limitation is that the method of plasma collection offers a possible explanation for lack of efficacy observed in the influenza trials. Only 1 trial $^{24}$ used plasma from individuals recovered from influenza in the prior 2 weeks. The other trials ${ }^{25-27}$ referred to their intervention as hyperimmune plasma and reported HAl titres that were quite high. ${ }^{25-27}$ The use of HAl for quantifying antibody activity of donor plasma has, however, proven controversial. ${ }^{40}$ Those who argue that HAl is of limited use might explain the negative results of 3 of the trials as a result of their failure to use truly convalescent plasma. ${ }^{40}$ This line of reasoning would suggest that trials studying the efficacy of convalescent plasma in COVID-19 should obtain plasma from recently recovered individuals and report the number of days since recovery of the donor along with information regarding serologic and functional assays on the plasma. Such a study design would markedly reduce doubts regarding the explanation of such studies failing to detect benefit.

\section{Conclusion}

The merit of convalescent plasma is its apparent low rate of serious adverse effects. Although this may be an advantage over other unproven therapies for COVID-19, it is insufficient to justify its use without associated evidence of efficacy. Collection of convalescent plasma consumes resources that, pending trustworthy evidence of positive effects, could be better allocated elsewhere. Widespread use of convalescent plasma should therefore await high-quality evidence from randomized trials, ideally testing the effect of plasma obtained from individuals recently recovered from COVID-19. Prioritization of clinical trials for testing efficacy of convalescent plasma over testing of other unproven therapeutic options for COVID-19 should be based not only on existing evidence but also on the sociopolitical context. The fact that clinicians have started using convalescent plasma in patients with COVID-19 in hospitals outside clinical trials makes it urgent to address its therapeutic value.

\section{References}

1. Coronavirus disease (COVID-2019) situation reports. Geneva: World Health Organization; 2020. Available: www.who.int/emergencies/diseases/novel-coronavirus -2019/situation-reports (accessed 2020 Apr. 27).

2. Wu Z, McGoogan JM. Characteristics of and important lessons from the coronavirus disease 2019 (COVID-19) outbreak in China: summary of a report of 72314 cases from the Chinese Center for Disease Control and Prevention. JAMA 2020 Feb. 24 [Epub ahead of print]. doi: 10.1001/jama.2020.2648.

3. Guan WJ, Ni ZY, Hu Y, et al., China Medical Treatment Expert Group for COVID-19. Clinical characteristics of coronavirus disease 2019 in China. N Engl J Med 2020;382:1708-20.

4. Zhou F, Yu T, Du R, et al. Clinical course and risk factors for mortality of adult inpatients with COVID-19 in Wuhan, China: a retrospective cohort study. Lancet 2020;395:1054-62

5. Wang $\mathrm{Y}$, Wang $\mathrm{Y}$, Chen $\mathrm{Y}$, et al. Unique epidemiological and clinical features of the emerging 2019 novel coronavirus pneumonia (COVID-19) implicate special control measures. J Med Virol 2020 Mar. 5 [Epub ahead of print]. doi: 10.1002/jmv.25748.

6. Mair-Jenkins J, Saavedra-Campos M, Baillie JK, et al.; Convalescent Plasma Study Group. The effectiveness of convalescent plasma and hyperimmune immunoglobulin for the treatment of severe acute respiratory infections of viral etiology: a systematic review and exploratory meta-analysis. J Infect Dis 2015; 211:80-90.

7. Zhang L, Liu Y. Potential interventions for novel coronavirus in China: a systematic review. J Med Virol 2020;92:479-90.

8. Lee JS, Adhikari NKJ, Kwon HY, et al. Anti-Ebola therapy for patients with Ebola virus disease: a systematic review. BMC Infect Dis 2019;19:376.

9. Stockman LJ, Bellamy R, Garner P. SARS: systematic review of treatment effects. PLoS Med 2006;3:e343.

10. Luke TC, Kilbane EM, Jackson JL, et al. Meta-analysis: convalescent blood products for Spanish influenza pneumonia: A future H5N1 treatment? Ann Intern Med 2006;145:599-609. 
11. Use of convalescent whole blood or plasma collected from patients recovered from Ebola virus disease for transfusion, as an empirical treatment during outbreaks. Geneva: World Health Organization; 2014. Available: www.who.int/csr/resources/ publications/ebola/convalescent-treatment/en (accessed 2020 Mar. 25).

12. Cheng $\mathrm{Y}$, Wong R, Soo YO, et al. Use of convalescent plasma therapy in SARS patients in Hong Kong. Eur J Clin Microbiol Infect Dis 2005;24:44-6.

13. Schoofs T, Klein F, Braunschweig M, et al. HIV-1 therapy with monoclonal antibody 3BNC117 elicits host immune responses against HIV-1. Science 2016;352:997-1001.

14. Ye Z, Rochwerg B, Wang Y, et al. Treatment of patients with nonsevere and severe coronavirus disease 2019: an evidence-based guideline. CMAJ 2020 May 4 [Epub ahead of print]. doi: 10.1503/cmaj.200648.

15. Moher D, Liberati A, Tetzlaff J, et al.; PRISMA Group. Preferred reporting items for systematic reviews and meta-analyses: the PRISMA statement. J Clin Epidemiol 2009;62:1006-12.

16. Clinical management of severe acute respiratory infection when COVID-19 is suspected [Interim guidance]. Geneva: World Health Organization; 2020. Available: www.who .int/publications-detail/clinical-management-of-severe-acute-respiratory-infection -when-novel-coronavirus-(ncov)-infection-is-suspected (accessed 2020 Mar. 21).

17. Guyatt G, Busse JW. Risk of bias in randomized trials. GROWTH Evidence; 2016. Available: https://growthevidence.com/gordon-h-guyatt-md-msc-and-jason -w-busse-dc-phd (accessed 2020 Mar. 24).

18. Guyatt GH, Busse J. Methods commentary: risk of bias in cohort studies. Ottawa: Evidence Partners. Available: www.evidencepartners.com/resources/ methodological-resources/risk-of-bias-in-cohort-studies (accessed 2020 Mar. 24).

19. Guyatt G, Oxman AD, Akl EA, et al. GRADE guidelines: 1. Introduction-GRADE evidence profiles and summary of findings tables. J Clin Epidemiol 2011;64:383-94.

20. Guyatt GH, Oxman AD, Santesso N, et al. GRADE guidelines: 12. Preparing summary of findings tables - binary outcomes. J Clin Epidemiol 2013;66:158-72.

21. Guyatt GH, Thorlund K, Oxman AD, et al. GRADE guidelines: 13. Preparing summary of findings tables and evidence profiles - continuous outcomes. J Clin Epidemiol 2013;66:173-83.

22. Higgins JPT, Green S, editors. 7.7.3.5. Medians and interquartile ranges. In: Cochrane Handbook for Systematic Reviews of Interventions. Version 5.1.0. Oxford (UK): Cochrane Collaboration; 2011. Available: https://handbook-5-1.cochrane.org/ chapter_7/7_7_3_5_mediansand_interquartile_ranges.htm (accessed 2020 Mar. 20).

23. Soo YO, Cheng Y, Wong R, et al. Retrospective comparison of convalescent plasma with continuing high-dose methylprednisolone treatment in SARS patients. Clin Microbiol Infect 2004;10:676-8.

24. Hung IFN, To KKW, Lee CK, et al. Hyperimmune IV immunoglobulin treatment: a multicenter double-blind randomized controlled trial for patients with severe 2009 influenza A(H1N1) infection. Chest 2013;144:464-73.

25. Beigel JH, Tebas P, Elie-Turenne MC, et al.; IRC002 Study Team. Immune plasma for the treatment of severe influenza: an open-label, multicentre, phase 2 randomised study. Lancet Respir Med 2017;5:500-11.
26. Beigel JH, Aga E, Elie-Turenne MC, et al.; IRC002 Study Team. Anti-influenza immune plasma for the treatment of patients with severe influenza $A$ : a randomised, doubleblind, phase 3 trial. Lancet Respir Med 2019;7:941-50.

27. Davey RT Jr, Fernández-Cruz E, Markowitz N, et al.; INSIGHT FLU-IVIG Study Group. Anti-influenza hyperimmune intravenous immunoglobulin for adults with influenza A or B infection (FLU-IVIG): a double-blind, randomised, placebo-controlled trial. Lancet Respir Med 2019;7:951-63.

28. van Griensven J, Edwards T, de Lamballerie X, et al. Ebola-Tx Consortium. Evaluation of convalescent plasma for Ebola virus disease in Guinea. N Engl J Med 2016; 374:33-42.

29. Recommendations for investigational COVID-19 convalescent plasma. Silver Sprint (MD): US Food and Drug Administration; 2020. Available: www.fda.gov/ vaccines-blood-biologics/investigational-new-drug-ind-or-device-exemption-ide -process-cber/investigational-covid-19-convalescent-plasma-emergency-inds (accessed 2020 Mar. 26)

30. Kalil AC. Treating COVID-19-off-label drug use, compassionate use, and randomized clinical trials during pandemics. JAMA 2020 Mar. 24 [Epub ahead of print]. doi: $10.1001 /$ jama.2020.4742.

31. Zhou XZ, et al. Epidemiologic features, clinical diagnosis and therapy of first cluster of patients with severe acute respiratory syndrome in Beijing area [article in Chinese]. Zhonghua Yi Xue Za Zhi 2003;83:1018-22.

32. Xu Z, Zhou J, Huang Y, et al. The efficacy of convalescent plasma for the treatment of severe influenza. medRxiv 2020 Feb. 25. doi: 10.1101/2020.02.20.20025593.

33. COVID-19 SARS-CoV-2 preprints from medRxiv and bioRxiv. medRxiv; 2020. Available: https://connect.medrxiv.org/relate/content/181 (accessed 2020 Mar. 11).

34. INSIGHT FLU005 IVIG Pilot Study Group. INSIGHT FLU005: an anti-influenza virus hyperimmune intravenous immunoglobulin pilot study. J Infect Dis 2016; 213:574-8

35. Shen C, Wang Z, Zhao F, et al. Treatment of 5 critically ill patients with COVID-19 with convalescent plasma. JAMA 2020 Mar. 27 [Epub ahead of print]. doi: 10.1001/jama.2020.4783.

36. Duan K, Liu B, Li C, et al. Effectiveness of convalescent plasma therapy in severe COVID-19 patients. Proc Natl Acad Sci U S A 2020;117:9490-6.

37. Zhang B, Liu S, Tan T, et al. Treatment with convalescent plasma for critically ill patients with SARSCoV-2 infection. Chest 2020 Mar. 31 [Epub ahead of print]. pii: S0012-3692(20)30571-7. doi: 10.1016/j.chest.2020.03.039.

38. Mulangu S, Dodd LE, Davey RT Jr, et al.; PALM Consortium Study Team. A randomized, controlled trial of Ebola virus disease therapeutics. N Engl J Med 2019;381:2293-303.

39. Shi Y, Wang Y, Shao C, et al. COVID-19 infection: the perspectives on immune responses. Cell Death Differ 2020;27:1451-4.

40. Kanjilal S, Mina MJ. Passive immunity for the treatment of influenza: quality not quantity. Lancet Respir Med 2019;7:922-3.
Competing interests: Mark Loeb has received personal fees and nonfinancial support from Sanofi, nonfinancial support from the World Health Organization, grant funding and personal fees from Seqirus, and personal fees from Pfizer, Medicago and the National Institutes of Health. Philippe Bégin is the co-principal investigator of a multicentre randomized controlled trial investigating the use of convalescent plasma in coronavirus disease 2019 (COVID-19). Philippe Bégin reports personal fees from Novartis, Pfizer, Sanofi, ALK and Aralez, as well as grants from DBV Technologies, Regeneron and Sanofi outside the submitted work. No other competing interests were declared.

This article has been peer reviewed.

Affiliations: Indian Institute of Public Health-Delhi (Devasenapathy), Public Health Foundation of India, Gurgaon, Haryana, India; Department of Health Research Methods, Evidence and Impact (Ye, Loeb, Fang, Tadayon Najafabadi, Xiao, Couban, Guyatt), McMaster University, Hamilton, Ont.; Guangzhou University of Chinese Medicine (Fang), Guangzhou, Guangdong, China; West China School of Nursing and West China Hospital (Xiao), Sichuan University, Chengdu, Sichuan, China; Department of Medicine (Bégin), Université de Montréal, Que.

Contributors: Niveditha Devasenapathy was responsible for the systematic review, performed the meta-analyses, interpreted the results, wrote the first draft of the manuscript and had final responsibility for the decision to submit for publication. Gordon Guyatt approved the review methodol- ogy, interpreted the results, provided critical comments on the manuscript and approved the final draft. Fang Fang and Yingqi Xiao were involved in the search of Chinese databases. Borna Tadayon Najafabadi was involved in the screening of eligible studies and data extraction. Zhikang Ye was involved in the systematic review design and interpretation of results. Fang Fang, Yingqi Xiao and Borna Tadayon Najafabadi were involved in screening and data extraction. Mark Loeb and Philippe Bégin were involved in the interpretation of the study results and provided critical comments on the manuscript. Rachel Couban is a medical information specialist and designed the search strategy and conducted the search. All of the authors revised the manuscript for important intellectual content. Niveditha Devasenapathy, Gordon Guyatt and Zhikang Ye had full access to all the data in the study. All of the authors gave final approval of the version to be published and agreed to be accountable for all aspects of the work.

Data sharing: Data extracted from the included studies are presented in the results; however, full extraction data tables are available on reasonable request from the corresponding author.

Acknowledgement: The authors thank Quazi Ibrahim for statistical advice. Yingqi Xiao is supported by the China Scholarship Council (no. 201906240082).

Accepted: May 1, 2020

Correspondence to: Niveditha Devasenapathy, niveditha@iiphd.org 